\title{
Linking Food Security, Migration and Development
}

\author{
Jonathan Crush*
}

\begin{abstract}
The issue of food security is strikingly absent from current debates about the relationship between migration and development. The current international food security agenda displays a similar disregard for migration. There thus appears to be a massive disconnect between these two global development agendas. The reasons are hard to understand since the connections between migration and food security seem obvious. This article addresses possible reasons for the disconnect and then presents and discusses the implications for linking migration and food security of a recent survey in 11 African cities. The results show a consistent pattern of difference between urban migrant and non-migrant households in relation to levels of food insecurity, sources of income, food procurement strategies, and participation in urban agriculture. This article therefore seeks to initiate a conversation between the separate worlds of migration and development on the one side, and food security on the other.
\end{abstract}

\section{POLICY IMPLICATIONS}

- The international food security agenda needs to consider the growing challenge of feeding rapidly growing cities with large migrant populations.

- The reality of internal and international migration should be mainstreamed into the food security agendas of international organisations and states.

- Food security and insecurity should be configured into the global debate on migration and development.

- International, regional and municipal policies need to pay particular attention to the food insecurity of migrant populations in cities of the South.

\section{INTRODUCTION}

Over the last decade, two issues have risen to the top of the international development agenda: (a) Migration and Development; and (b) Food Security. Each has its own international agency champions (the International Organisation for Migration and the UN Food and Agriculture Organisation), its own international gatherings (the World Forum on Food Security and the Global Forum on International Migration), its own national line ministries (Departments of Immigration and Home Affairs and Departments of Agriculture and Food Security) and its own voluminous body of research and scholarly publications. Some international organizations (such as the World Bank) deal with both issues but in such separate silos that they might as well be in separate orga-

\footnotetext{
* University of Cape Town and Balsillie School of International Affairs.
} 
nizations. There appears, in other words, to be a massive institutional and substantive disconnect between these two development agendas. The reasons are hard to understand since the connections between migration and food security seem obvious. Indeed, one cannot be properly understood and addressed independently of the other.

Global and regional discussions about the relationship between migration and development cover a broad range of policy issues such as remittance flows, the brain drain, the role of diasporas and circular migration (Global Commission on International Migration, 2005; UN General Assembly, 2006; Castles and Wise, 2008; UNDP 2009). Strikingly absent from these discussions is any systematic reflection on the relationship between migration and food security. There are a number of possible reasons for this. Firstly, discussions of the impact of migration on development tend to be pitched at the global and national scale and focus on economic growth and productive investment. Secondly, when discussion turns to the household level, the debate focuses largely on remittance flows and the use of remittances by the household. There is a common view that the expenditure of remittances on basic livelihood needs is somehow non-developmental in that it does not lead to investment and sustainable productive activity (Crush and Pendleton, 2009). Not only is this an extremely narrow perspective, it also means that the food needs of households (and their food security more generally) are rarely given much consideration as development objectives and outcomes. Thirdly, while this debate does seek to understand the drivers of migration, it seems to ignore food shortages and insecurity as a basic cause of migration and it certainly seems to forget that migrants themselves have to eat in the towns and cities to which they migrate. Finally, discussions of migration and development tend to focus more on international than internal migration. Food security is certainly affected by international migration (for example, households in Zimbabwe rely heavily on remittances from around the world to purchase food and other necessities). However, the relationship between migration and food security is particularly important within national boundaries.

If the global migration and development debate sidelines food security, the current international food security agenda has a similar disregard for migration. The primary reason for this is the way in which "food security" is currently problematized. The overwhelming consensus seems to be that food insecurity is primarily a problem affecting the rural poor and that the solution is a massive increase in agricultural production by small farmers (Frayne and Crush, 2011). The influential Alliance for a Green Revolution in Africa (AGRA), for example, was established "to achieve a food secure and prosperous Africa through the promotion of rapid, sustainable agricultural growth based on smallholder farmers" (see http://www.agra-alliance.org/). In much of the thinking about rural food insecurity, therefore, there is an implicit assumption that Africa's rural areas are bounded territories whose main problem is that households do not produce enough food for themselves. By drawing boundaries around the "rural" in this way, there is a tendency to ignore the reality that migration is a critical food security strategy for rural households up and down the African continent. Any intervention to improve the food security of rural populations therefore needs to acknowledge that migration both deprives rural households of agricultural labour and provides them with the remittances to purchase agricultural inputs and foodstuffs. Rural households purchase a good deal of their food with cash that they receive from absent household members who are working in other parts of a country or in other countries altogether. Rural food insecurity is therefore not simply about how much a household produces from the land; often it is more about the fact that remittances from migrants are too small or too irregular to allow households to purchase sufficient food of good quality.

The rural focus of the international food security agenda is likely to determine the way in which the relationship between migration and food security is eventually understood. A recent issue of the journal Food Policy, for example, suggests that "the sending of a migrant means the loss or reduced presence of one or more members of the household. On the consumption side this clearly means fewer mouths to feed and to support in other ways. On the production side, migration means the loss of labor and, in fact, the negative consequences of migration on nutrition are likely to 
come through this labor loss" (Zezza et al., 2011: 2). The major positive impact of migration is the remittances sent home by the migrant which can have direct and indirect effects on production and consumption (Vargas-Lundius, Lanly, Villarreal and Osorio, 2008).

Implicit in this analysis is a prioritization of the impact of migration on the food security of the rural household. Similarly, in its input to the $10^{\text {th }}$ UN Coordination Meeting on International Migration in January 2012, the FAO focuses almost exclusively on migration, agriculture and rural development (FAO, 2012). Attention to the connections between migrant remittances and rural food security certainly challenge the conventional notion of the rural household as a self-contained entity wholly dependent on smallholder production. However, it does not take us far enough in addressing the full range of impacts that migration has on food security, including the food security of the permanent and temporary residents of the region's towns and cities.

Many poor urban households in African cities are made up entirely or partially of migrants. Rural to urban migration is rarely a one-way, one-time move, however. Many urban dwellers speak of and feel attached to a rural home. Households in Africa are often spatially stretched between rural and urban spaces and occupied by different members of the kin group at different times. The reality on the ground, then, is that the distinction between "the rural" and "the urban" is an "obsolete dichotomy" in Africa (Lerner and Eakin, 2011; see also Champion and Hugo, 2004; Lynch, 2005). As Ellis and Harris maintain: "It is not very helpful to treat 'rural areas' as undifferentiated territories that exhibit definitively distinct features from "urban areas"” (Ellis and Harris, 2004: 13). Households are not static self-contained rural or urban units but fluid entities with permeable boundaries whose degree of food security is constantly and profoundly shaped by the mobility of people in a continent "on the move" (Tienda et al., 2006; Crush and Frayne, 2010). If we accept this general argument, it immediately becomes clear that it would be unwise to drive a wedge between rural and urban food security as if they had very little relationship with or impact on one another. On the contrary, not only are they inter-related but migration becomes an important key to unlocking this relationship (Zezza et al., 2011).

In summary, food security needs to be "mainstreamed" into the migration and development agenda and migration needs to be "mainstreamed" into the food security agenda (Ruel et al., 2008). Without such an effort, these agendas will continue to proceed in ignorance of the other to the detriment of both. The result will be a singular failure to understand, and manage, the crucial reciprocal relationship between migration and food security. This article sets out to promote a conversation between the food security and migration agendas in the Southern African context in the light of what we know and what we need to know about their connections. The primary focus is on urban food security and urbanization.

\section{INTERNAL MIGRATION AND URBAN FOOD SECURITY}

Rapid urbanization is a distinguishing characteristic of contemporary Africa and a great deal of this urban growth is fuelled by migration. The urban population of SADC increased from 20.5 million in 1990 to an estimated 34 million in 2010 (UN-HABITAT, 2010: 207). ${ }^{1}$ UN-HABITAT predicts that it will increase further to 39 million in 2020 and 52 million in 2030. At present 38 per cent of the population is urbanized, a figure projected to pass 50 per cent in the next 20 years and to rise to 75 per cent by mid-century (Figure 1). In 1990, only South Africa was more than 50 per cent urbanized. By 2050, all Southern African countries except Swaziland are projected to be over 50 per cent urbanized (Table 2). Urbanization rates will exceed 75 per cent in Angola, Botswana and South Africa.

Evidence for rapid urbanization in Africa should not be interpreted as a permanent one-time rural-to-urban shift or that rural areas are undergoing an inevitable process of depopulation. Certainly the overall trend is towards more people living for longer periods in towns and cities. But this does not mean that they are necessarily cutting all links to the countryside. Indeed, there is 
FIGURE 1

SOUTHERN AFRICAN URBAN POPULATION TRENDS AND PROJECTIONS, 1950-2050

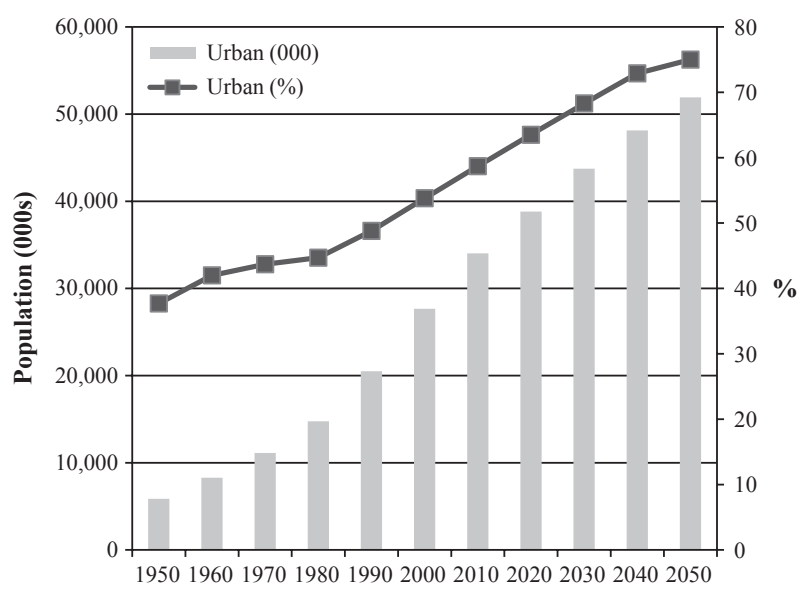

considerable evidence that most first-generation migrants retain very close ties with their rural homesteads. This adds layers of complexity to our understanding of migration dynamics and impacts.

South Africa has the highest proportion of urban dwellers of all SADC countries (60-70 per cent) and appears closest to the model of a classic "urban transition" (Cox et al., 2004). A progressively greater proportion of the population lives permanently in towns and cities, not least because the rural areas of the country do not offer households the prospect of a decent livelihood or many future prospects (Kok et al., 2003; Kok and Collinson, 2006; Posel and Casale, 2006). Cumulative migration (the number of people living in a province other than their province of birth) was 5.5 million in 2001, or more than 10 per cent of the total South-African born population. The South African Cities Network calculated that the seven largest urban municipalities in South Africa attracted over 500,000 additional migrants between 2001 and 2006 (South African Cities Network, 2006: 218).

Simply because urbanization is proceeding rapidly, it does not mean that individuals or households who move are cutting their links with rural areas. Is circular migration a significant phenomenon in South Africa (Posel and Casale, 2003; Posel, 2006; Todes et al., 2010)? Based on their work in rural and peri-urban communities in the eastern part of the country, Collinson et al. argue for the existence of "highly prevalent circular migration" between rural and urban areas and note a marked increase in temporary female migration (Collinson et al., 2006; Collinson, 2010). In South Africa as a whole, 33 per cent of all rural households reported at least one migrant member in 1993. By 2002, this figure had increased to 38 per cent (an increase of 300,000 households) (Posel and Casale, 2006). In the last decade, it has begun to fall again as migrants (and households) settle more permanently in urban areas (Posel, 2010). The number of households with a migrant member dropped from 2.2 million in 1993 to 1.6 million in 2008 (a fall to 30\% of all households).

Potts has recently reviewed the empirical evidence on urbanization trends in Sub-Saharan Africa and argues that the idea that migration is a permanent move to urban areas is misplaced (Potts, 2010). Drawing on a range of empirical sources, and her tracking of migration trends in Zimbabwe, she argues that "circulation" between rural and urban areas is still a defining characteristic of African urbanization and internal migration:

Circular migration between rural and urban areas remains a crucial, and adaptable, aspect of urbanization processes in sub-Saharan Africa... The scale, duration and direction of such migration flows have adapted in logical ways to the increasing poverty in urban areas that accompanied structural 
adjustment, and net in-migration has been reduced, sometimes very markedly. These adaptations are mainly the result of very negative livelihood changes for most of the urban population for whom there is no economic safety net, if all else fails, except within the nexus of rural-urban linkages (Potts, 2010: 29).

Various household surveys by Potts and others suggest that the dynamics of urbanization, circular migration and rural-urban linkage are complex and highly variable. As Potts notes, "migrants in town include different types of people with different histories, aspirations and social connections with their place of origin" (Potts, 2010:193; Potts, 2006; Potts, 2008).

Given the high rates of urbanization in Southern Africa, migrants have a visible presence in the region's towns and cities. The African Food Security Urban Network (AFSUN) found that poor neighbourhoods in most cities were dominated by migrants (Frayne et al., 2010). Of the 6,453 urban households interviewed in 11 SADC cities, 38 per cent were first-generation migrant households (that is, every member of the household was born outside the city). In contrast, only 13 per cent of households had no migrant members. The remainder (nearly half) comprised a mix of migrants and non-migrants, usually households in which the adults were migrants and the children were born in the city. The relative importance of migrants did vary from city to city, however. All of the cities had a comparatively small proportion of non-migrant households (ranging from a low of five per cent in the case of Gaborone to a high of 20 per cent in the case of Johannesburg). In other words, in every city 80 per cent or more of the households were either composed entirely of migrants or had some migrant members. The biggest difference was in the relative number of migrant households (from a high of 67 per cent in Gaborone to a low of 9 per cent in Harare).

At a general level these differences are attributable to each country's distinctive history of urbanization. The four ex-apartheid cities (Cape Town, Johannesburg, Msunduzi and Windhoek) all have relatively high numbers of pure migrant households, a pattern that is broadly consistent with mass rural to urban household migration following the collapse of apartheid. Cities in countries that have been independent for a longer period (such as Malawi, Swaziland and Zambia) tend to have more mixed households and fewer purely migrant households. In those countries, independence was accompanied by rapid in-migration to primate cities and those urbanites have been in the cities long enough to have second- and even third-generation members born in the city. Mozambique and Zimbabwe became independent later and were also severely affected by pre-independence civil conflict and post-independence economic crisis. These two cities have an extraordinarily high num-

TABLE 1

PROPORTION OF MIGRANT AND NON-MIGRANT HOUSEHOLDS

\begin{tabular}{|l|ccc|}
\hline City & $\begin{array}{c}\text { Migrant Households } \\
\text { (\% of Total) }\end{array}$ & $\begin{array}{c}\text { Mixed Households } \\
\text { (\% of Total) }\end{array}$ & $\begin{array}{c}\text { Non-Migrant Households } \\
\text { (\% of Total) }\end{array}$ \\
\hline Gaborone & 67 & 28 & 5 \\
Cape Town & 54 & 40 & 6 \\
Msunduzi & 48 & 43 & 9 \\
Windhoek & 49 & 40 & 11 \\
Johannesburg & 42 & 35 & 23 \\
Maseru & 37 & 52 & 11 \\
Manzini & 32 & 55 & 13 \\
Lusaka & 24 & 56 & 20 \\
Blantyre & 17 & 65 & 18 \\
Maputo & 11 & 78 & 13 \\
Harare & 9 & 78 & 13 \\
Total & 38 & 49 & \\
\hline
\end{tabular}


TABLE 2

MONTHLY EXPENSES OF MIGRANT-SENDING HOUSEHOLDS

\begin{tabular}{|l|ccr|}
\hline Expenditure Item & $\begin{array}{c}\text { \% of Households } \\
\text { Spending Cash } \\
\text { Income on Item }\end{array}$ & $\begin{array}{c}\text { \% of Households Spending } \\
\text { Remittances on Item }\end{array}$ & $\begin{array}{c}\text { Average Monthly } \\
\text { Expense (ZAR) }\end{array}$ \\
\hline Food and groceries & 93 & 82 & 288 \\
Housing & 9 & 10 & 9 \\
Utilities & 38 & 30 & 36 \\
Clothes & 42 & 52 & 267 \\
Medical expenses & 30 & 20 & 24 \\
Transportation & 44 & 34 & 48 \\
Education & 31 & 52 & 91 \\
Entertainment & 3 & 3 & 18 \\
Savings & 17 & 12 & 200 \\
Fuel & 44 & 10 & 58 \\
Farming & 15 & 10 & 534 \\
Building & 8 & 8 & 239 \\
Special events & 8 & 3 & 55 \\
Gifts & 4 & 1 & 81 \\
Other expenses & 2 & & \\
\hline
\end{tabular}

Source: SAMP

ber of mixed households (nearly 80 per cent). The obvious anomaly in the survey is Gaborone with two-thirds of its households consisting entirely of migrants. Gaborone has been urbanizing much faster than either Manzini or Maseru (with which it is often compared) (see Table 1), a reflection of the fact that Botswana's economy is much more vibrant than that of Lesotho or Swaziland, drawing more migrant households from the countryside to the city.

Rapid urbanization certainly effects massive change in the volume and nature of what a growing city eats. However, conceptualizations of migration and food security need to take account of the reality of "highly mobile urban and rural populations, coupled with complex, fluid households" (Hosegood and Timæus, 2005). The concept of the "stretched household" seems most relevant to breaking down the artificial wall between the urban and the rural and between rural and urban food security. Firstly, it more closely approximates a reality in which migrants "continue to be members of rural households whilst forming or joining other households in an urban area" (Ibid: 10). Secondly, it emphasizes the complex connections between the urban and the rural: "The notion of a "divide" (between the rural and the urban) has become a misleading metaphor, one that oversimplifies and even distorts realities... The linkages and interactions have become an ever more intensive and important component of livelihoods and production systems in many areas forming not so much a bridge over a divide as a complex web of connections in a landscape where much is neither 'urban' nor 'rural'" (Tacoli, 2003: 3). Thirdly, the concept highlights the fact that urban and rural food security are often inter-dependent at the level of the individual household.

As urban-urban migration increases (for example, from smaller urban centres to large cities) within countries and across borders, "stretched households" are also emerging in the purely urban context. In Lesotho, for example, many urban households in the capital city of Maseru have members working in South African towns and cities. The Namibian National Migration Survey in found that urban-urban migration made up 20 per cent of lifetime migration moves (Pendleton and Frayne, 2001). In South Africa, the "fluidity, porosity and spatially 'stretched' nature of households" has been observed. Household fluidity relates to the "contested nature" of household membership, the claims of non-core urban household members on household resources and the "spatially 
extended nature of the links and resource flows thus created" (du Toit and Neves, 2009a; see also Bekker, 2001; Bank and Minkley, 2005; du Toit and Neves, 2007; du Toit and Neves, 2009b). As a result, the density of exchanges between the two (primarily of people, goods, cash and social grants) impacts on the food security of stretched households (du Toit and Neves, 2009: 39-40). Increasingly, multi-nodal households are emerging, stretched between two or more locations. In Maputo, poor urban households are stretched to include the Mozambican countryside and urban areas in South Africa. In other words, a "household" may well have migrant members living, working and otherwise making do in more than one city in the country or region. This adds yet another level of complexity and fluidity to household food security strategies.

\section{INTERNATIONAL MIGRATION AND URBAN FOOD SECURITY}

The simplest way to examine the relationship between cross-border migration and food security is to ascertain (a) how international migrants address their own food and nutrition needs in the destination country and (b) what happens to the income that they earn while away from home. The two questions are not unrelated, for the amount of money available to send home is to some degree contingent on the food-related expenditures of the migrant in the destination country. This is not as simple as it sounds because the food-related draw on income in the destination country may extend well beyond the individual migrant's own needs. Migrants rarely live alone and their income may often have to support members of "makeshift" households (not all of whose members can find work) as well as second households. One of the recurrent complaints of partners of male migrants in Lesotho and Mozambique, for example, is that they receive less money from their partners because they support second families in South Africa as well (Crush et al., 2010).

The Southern African Migration Programme (SAMP) has conducted major household surveys in several SADC countries and provides valuable information on food expenditures in migrant-sending households (Pendleton et al., 2007; Dodson, 2008). A regional study of 4,276 households with international migrants found that cash remittances are the most important source of income with 74 per cent of all migrant-sending households receiving remittances (with as many as 95 per cent in Lesotho and 83 per cent in Zimbabwe). In-country wage employment is a source of income for 40 per cent of households followed by remittances in kind (37 per cent). Remittances in-kind are particularly important in Zimbabwe and Mozambique. At the other end of the spectrum, only eight per cent of households receive income from the sale of agricultural produce and only five per cent receive social grants (mainly in Botswana).

The vast majority of households (93 per cent) purchase food and groceries with their income (Table 2). No other expenditure category comes close although a significant minority of households pay for cooking fuel, transportation, clothing, utilities, education and medical expenses. A mere 15 per cent spend income on agricultural inputs (mainly in Swaziland). The proportion of households spending remittances on food was over 80 per cent. Average household expenditures on food were ZAR288 per month which is much greater than the amounts spent on other common categories such as transportation, education and medical expenses. The average monthly expenditure of remittances on food was ZAR150 per month. In other words, remittances provided over 50 per cent of average household income spent on food. Without remittances the amount being spent on food would drop precipitously. Remittances are therefore a critical component of food security for migrant-sending households. Unsurprisingly, 82 per cent of households said that remittances were "very important" and another 18 per cent that they were "important" to meeting household food needs.

The study found that 28 per cent of households spend more than 60 per cent of their income on food. This varied considerably from country to country, ranging from 13 per cent in the case of Zimbabwe to 40 per cent in Mozambique. Even with remittances, only 17 per cent said that they always had or almost always had enough food in the previous year. Again this varied from country 
to country with only two per cent of households in Zimbabwe saying they always or almost always had enough food. Mozambique returned the highest figure, but still only 24 per cent.

Cash remittances are not the only way in which migration contributes to household security, as many migrants also send food back home as part of their in-kind remittance "package." Further proof of the importance of migration to household food security and other basic needs is provided in the types of goods that migrants send home. There was little evidence of luxury goods being sent. Instead, clothing (received by 41 per cent of households) and food (received by 29 per cent) were the items most frequently brought or sent. In the case of Mozambique, 60 per cent of households received food and in Zimbabwe, 45 per cent.

\section{MIGRANT AND NON-MIGRANT HOUSEHOLDS IN THE CITY}

Are migrants more or less food insecure than longer-term residents of the poorer areas of Southern African cities? The question is a difficult one to answer for a number of reasons. Firstly, the food security of the urban and rural members of a household are inter-linked. One of the main reasons for temporary migration to urban areas is to earn income to remit to rural household members. Migrants in the city may sacrifice their own food security in order to remit and ensure that rural relatives have enough to eat. Secondly, in a region in which the majority of the food consumed by urban households is purchased, the food security of migrants is highly contingent on their ability to earn income in the urban formal or informal economy. Thirdly, there may be significant differences between internal and cross-border migrants in terms of access to urban employment and other income-generating activity. All of these issues require much further research before we can draw definitive conclusions.

The 2008 AFSUN urban food security baseline survey provides an opportunity for a much broader regional comparison of migrant and non-migrant households in the poorer neighbourhoods of cities. Given the centrality of food purchase to urban food security, access to income is a critical issue. Are established non-migrant households more or less likely to access regular and reliable sources of income, both formal and informal? In general, the income source profile for migrant and non-migrant households is similar (Figure 2). Across the sample as a whole, unemployment rates are high with nearly half of both migrant and non-migrant households receiving no income from regular wage work. This suggests that migrants are no more or less likely to obtain wage employment than permanent residents in the city, a finding of some significance

FIGURE 2

SOURCES OF HOUSEHOLD INCOME

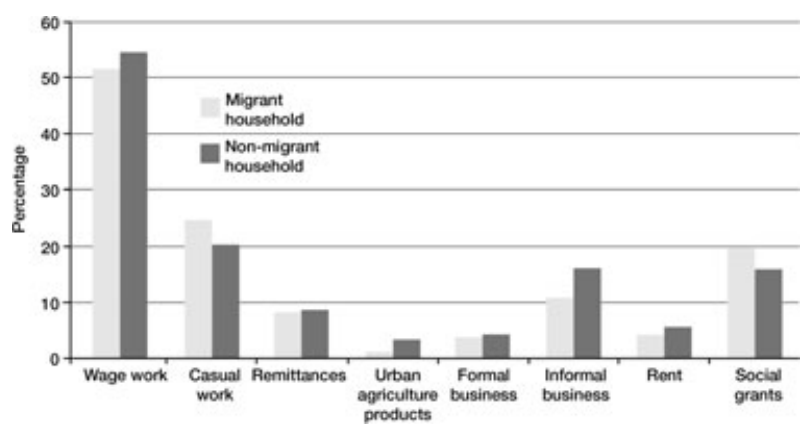


since it is often assumed that migrants have a harder time finding work than those born and bred in a city.

Migrant households do seem to find it easier to derive income from casual work (Figure 2). A number of other small differences emerged. First, non-migrant households were more involved than migrant households in running informal and formal businesses (20 per cent versus 14 per cent). This suggests it may be easier for permanent residents of the city to access the resources (such as credit) to run and grow a business. Secondly, although very few households in either category earn any income from the sale of home-grown agricultural produce, non-migrant households did seem a little more likely to engage in urban agriculture, presumably because they have readier access to land through home ownership. Thirdly, migrant households were slightly more likely than nonmigrant households to be receiving social grant income (19 per cent and 16 per cent). The difference is not large but it suggests that migrant households eligible to receive social grants are able to access them even if they are not in their home area.

The similarities in the access of migrant and non-migrant households to the labour market and to various income-generating activities suggest that they might have similar income levels and, in turn, levels of food security. In fact, there was one distinct difference in the income profile of migrant and non-migrant households (Figure 3). About a third of the households in each group fell into the lowest income tercile. However, 36 per cent of non-migrant households were in the upper income tercile, compared with only 29 per cent of migrant households. The situation was reversed with the middle income tercile. In other words, migrant status is not a completely reliable predictor of whether a household will be income poor. However, non-migrant households are likely to have a better chance of having better incomes, primarily because some are able to access better-paying jobs.

Since urban households purchase the bulk of their food, non-migrant households might have a better chance of being food secure than migrant households. The Household Food Insecurity Scale (HFIAS) measures access to food on a 0 (most secure) to 27 (most insecure) point scale. The mean and median score for all households in the survey was 10, suggesting widespread food insecurity. Individual city means varied from a low of 5 in Johannesburg to a high of 15 in Harare (Frayne et al., 2008: 28). In terms of the relationship between the HFIAS and food security, migrant households had a mean score of 10.5 and a median of 10 . Non-migrant households had lower scores of 8.9 and 8 respectively. Although the differences are not large, the results confirm that non-migrant households are more likely to be food secure than migrant households.

FIGURE 3

INCOME TERCILES

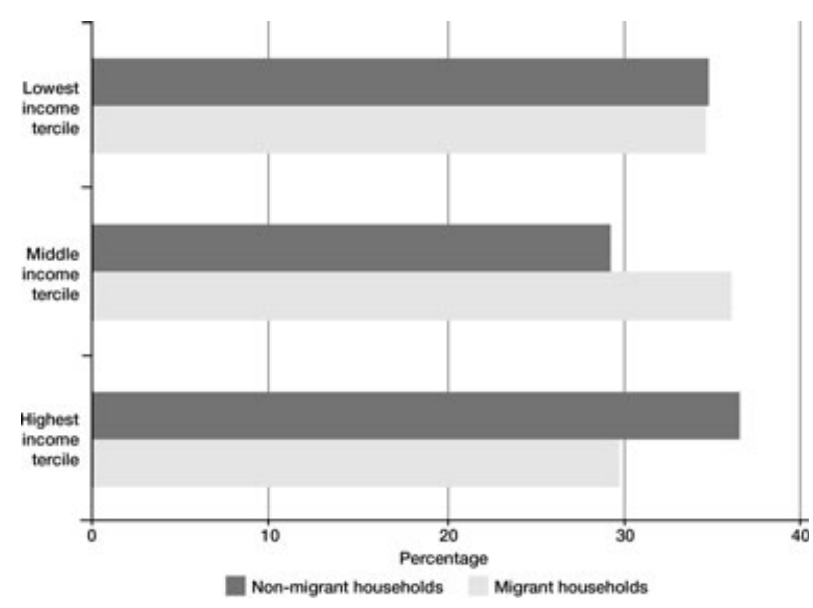


This finding is given added weight by the Household Food Insecurity Access Prevalence (HFIAP) Indicator. Only 16 per cent of migrant households can be categorized as food secure using the HFIAP Indicator, compared with 26 per cent of non-migrant households (Figure 4). At the opposite end of the scale, 61 per cent of migrant households were severely food insecure, compared with only 48 per cent of non-migrant households. Or again, 78 per cent of migrant households are either moderately or severely food insecure, compared with 65 per cent of non-migrant households. Although levels of food insecurity are disturbingly high for both types of household, migrant households stand a greater chance of being food insecure.

Another dimension of food insecurity is dietary diversity. The Household Dietary Diversity Scale (HDDS) measures how many food groups have been eaten by household members in the previous 24 hours (up to a maximum of 12). Most poor migrant and non-migrant households do not have a particularly diverse diet. For example, nearly half of both groups consumed food from five or fewer food groups, and nearly a quarter from three or fewer food groups (Table 3). The main difference between the two groups comes at the other end of the scale where diverse diets are more frequent among non-migrant than migrant households. For example, 28 per cent of migrant households consumed food from seven or more food groups, compared with 38 per cent of all non-migrant households. In other words, non-migrant households are generally likely to have a more diverse diet.

Another question is whether there are any differences between migrant and non-migrant households in where they obtain their food in the city. Migrant households were more likely than non-migrant households to patronize supermarkets (Figure 5). The opposite was true of the

FIGURE 4

FOOD SECURITY OF MIGRANT AND NON-MIGRANT HOUSEHOLDS

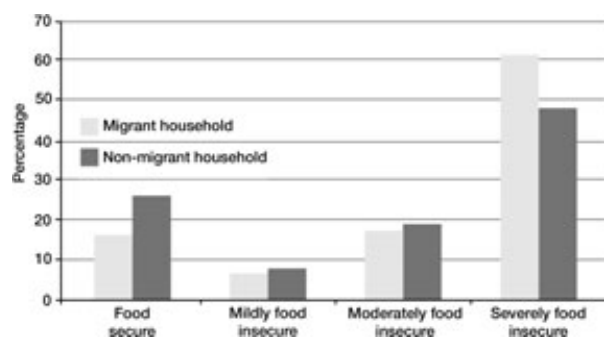

TABLE 3

HOUSEHOLD DIETARY DIVERSITY

\begin{tabular}{|l|cc|}
\hline No. of Food Groups & Migrant Households (\%) & Non-Migrant Households (\%) \\
\hline 1 & 3 & 4 \\
2 & 11 & 10 \\
3 & 10 & 9 \\
4 & 10 & 10 \\
5 & 13 & 12 \\
6 & 12 & 11 \\
7 & 12 & 10 \\
8 & 12 & 12 \\
9 & 8 & 8 \\
10 & 4 & 5 \\
11 & 2 & 4 \\
12 & 3 & 5 \\
\hline
\end{tabular}


FIGURE 5

SOURCES OF FOOD FOR MIGRANT AND NON-MIGRANT HOUSEHOLDS

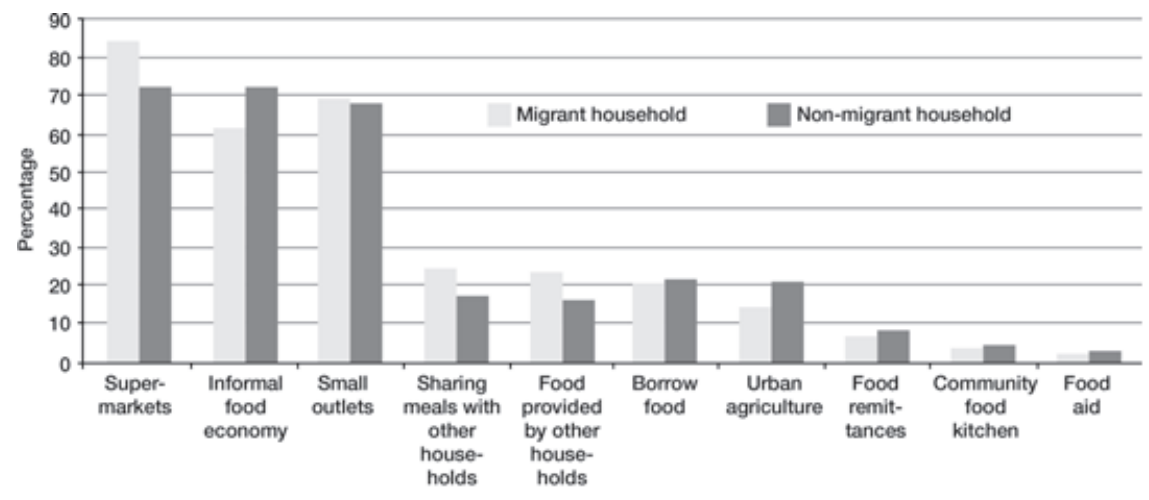

informal food economy. The reason for this difference is not immediately apparent but may have to do with the fact that non-migrant households would be more familiar with alternative food sources compared with recent in-migrants, who would be more likely to know about and recognise supermarket outlets. A second difference is the extent to which households rely on other households for food, either through sharing meals or food transfers. This was more common among migrant than non-migrant households, suggesting the existence of stronger social networks amongst migrants. Thirdly, and unsurprisingly given their greater degree of access to land for gardens, nonmigrant households were more likely to grow some of their own food than migrant households.

\section{CONCLUSION}

Migration within and to the Southern African region has changed dramatically in recent decades. All of the evidence suggests that the region is undergoing a rapid urban transition through internal migration and natural population increase. There has also been significant growth in temporary cross-border movement within the region. The implications of the region's new mobility regime for food security in general (and urban food security in particular) need much further exploration and analysis. To what degree is heightened mobility related to problems of food insecurity? Food security shocks and chronic food insecurity can certainly be major motives for migration for income-generating opportunity. War and conflict, particularly in Angola and the Democratic Republic of the Congo (DRC), led to the displacement of millions who fled to neighbouring countries. The collapse of the Zimbabwean economy since 2000 has pushed hundreds of thousands of desperate food-insecure people out of the country. The meltdown has affected the poor but has also ravaged the urban middle-class leaving migration as the main "exit option". Chronic poverty and related food insecurity is also partially responsible for the upsurge in post-1990 migration from countries such as Lesotho, Mozambique, Malawi and Swaziland.

Current conceptualizations of the food security crisis in Africa provide an inadequate basis for working at the interface between migration and food security. First, there is the pervasive assumption that food security is primarily a rural problem that will be resolved through technical innovation amongst smallholders (in the guise of a new Green Revolution). What seems to be forgotten in this essentially romantic view of the African rural household is that its food security is not simply, or even mainly, a function of what it does or does not produce itself. Up and down the continent rural households purchase some or most of their food and they do so with cash that they 
receive from household members who have migrated to earn income in other places within the country and across borders. The evidence for Southern Africa, at least, is that these rural households do not invest remittances in agriculture but in basic necessities, including food purchase (Crush and Pendleton, 2009). Rural food security, in other words, may be improved but will not be resolved by current productionist approaches.

A second flawed assumption is that food security in urban areas is about promoting urban agriculture. Urban agriculture can certainly contribute to the food security of some households but it is very far from being a panacea for all (Crush, Hovorka and Tevera, 2011). The obsession with urban agriculture may be well-intentioned but it derives from the misplaced idea that increased food production is the key to urban food security. The primary determinant of food insecurity in African cities is not production shortfalls but the lack of access to food and that means the absence of a regular and reliable income with which to purchase it. Even within the poorest areas of the city, access varies considerably from household to household with wage employment, other income generating activity, the size and structure of the household, the educational level of the household members, access to social grants and being embedded in social networks. This article has also demonstrated that the migrant status of a household is a key determinant of food security. The differences between migrant and non-migrant households are relatively significant. While there are many poor and food insecure households in both camps, there are more food secure households in the non-migrant group.

A third problematic assumption is that the rural and urban are separate spheres with a deep divide between them. This dualistic view of the world is clearly at odds with the observable web of connections and flows that bind rural and urban spaces together. The concept of the stretched or multi-nodal household attempts to capture the reality that even at the micro-scale, there is regular circulation of people, goods and money between town and countryside. Conceptually and methodologically, this reality means that it is impossible to fully explain the state of food security of urban households without reference to their rural counterparts, and vice-versa. For example, one of the reasons why there are fewer food secure migrant households in the cities may be because, unlike non-migrant households, they remit a portion of their income to rural areas which are in even greater need of the cash. On the other hand, the situation of migrant households would be even more desperate but for relatively widespread intra-household rural-urban transfers of food.

The fourth assumption is that migration and mobility are of limited relevance to food security. There are some recent signs of recognition of the reality that migration and remittances play an important role in the food security strategies of rural households. What tends to be overlooked is the role of migration in the food security of urban households. As this article shows, the majority of households in poor areas in Southern African cities consist either entirely of migrants or a mix of migrants and non-migrants. Rapid urbanization, increased circulation and growing cross-border migration have all meant that the number of migrants and migrant households in the city has grown exponentially. This is likely to continue for several more decades as urbanization continues. We cannot simply assume that all poor urban households are alike. While levels of food insecurity are unacceptably high amongst all of them, migrant households have a greater chance of being food insecure with all of its attendant health and nutritional problems. This fact needs to be recognised by policy-makers and acted upon.

\section{ACKNOWLEDGEMENTS}

I would like to thank the Canadian International Development Agency (CIDA) for funding the research on which this article is based. The article is a revised and abridged version of the AFSUN 
working paper "Migration, Development and Urban Food Security" Urban Food Security Series No. 9, Cape Town, 2012.

\section{NOTE}

1. The UN-HABITAT data for Southern Africa includes the countries of Angola, Botswana, Lesotho, Mozambique, Namibia, South Africa, Swaziland, Zambia and Malawi but excludes other SADC countries such as the DRC, Malawi and Tanzania.

\section{REFERENCES}

Bank, L, and G. Minkley

2005 "Going nowhere slowly? land, livelihoods and rural development in the Eastern Cape", Social Dynamics, 31(1): 1-38.

Bekker, S.

2001 "Diminishing returns: circulatory migration linking Cape Town to the Eastern Cape", South African Journal of Demography, 8(1): 1-8.

Castles, S., and R. Wise, eds.

2008 Migration and Development: Perspectives from the South, IOM, Geneva.

Champion, A., G. Hugo, and eds.

2004 New Forms of Urbanization: Beyond the Rural-Urban Dichotomy, Gower, Aldershot.

Collinson, M.

2010 "Striving against adversity: the dynamics of migration, health and poverty in rural South Africa", Global Health Action, 3.

Collinson, M., S. Tollman, K. Kahn, et al.

2006 "Highly prevalent circular migration: households, mobility and economic status in rural South Africa”, in M. Tienda, S. Findley, S. Tollman and E. Preston-Whyte (Eds), Africa on the Move: African Migration and Urbanisation in Comparative Perspective. Wits University Press: Johannesburg: 194-216.

Cox, K., D. Hemson, and A. Todes

2004 "Urbanization in South Africa and the changing character of migrant labour in South Africa", South African Geographical Journal, 86(1): 7-16.

Crush, J., and B. Frayne, eds.

2010 Surviving on the Move: Migration, Poverty and Development in Southern Africa, SAMP and DBSA, Cape Town and Midrand.

Crush, J., and W. Pendleton

2009 "Remitting for survival: rethinking the development potential of remittances in Southern Africa", Global Development Studies, 5(3-4): 1-28.

Crush, J., A. Hovorka, and D. Tevera

2011 "Food security in Southern African cities: the place of urban agriculture", Progress in Development Studies, 11(4): 285-305.

Crush, J., B. Dodson, J. Gay, et al.

2010 Migration, Remittances and 'Development' in Lesotho, SAMP Migration Policy Series No. 52, Cape Town.

Dodson, B.

2008 "Gender, migration and remittances in Southern Africa", SAMP Migration Policy Series No. 49, Cape Town.

du Toit, A., and D. Neves

2007 In search of South Africa's 'second economy': chronic poverty, economic marginalisation and adverse incorporation in Mt Frere and Khayelitsha, Working Paper 1, Programme for Land and Agrarian Studies (PLAAS), University of Western Cape, Bellville. 
2009a Informal social protection in post-apartheid migrant networks: vulnerability, social networks and reciprocal exchange in the Eastern and Western Cape, South Africa, Working Paper 2, Programme for Land and Agrarian Studies (PLAAS), University of Western Cape, Bellville: 19-20.

2009b Trading on a grant: integrating formal and informal social protection in post-apartheid migrant networks, Working Paper 3, Programme for Land and Agrarian Studies (PLAAS), University of Western Cape, Bellville.

Ellis, F., and N. Harris

2004 Development patterns, mobility and livelihood diversification, Keynote Paper for DFID Sustainable Development Retreat, University of Surrey, Guildford: 13.

FAO

2012 Input of the food and agriculture organization of the United Nations to the tenth coordination meeting on international migration, Population Division, Department of Economic and Social Affairs, United Nations Secretariat, New York.

Frayne, B., and J. Crush

2011 "Urban food insecurity and the new international food security agenda", Development Southern Africa, 28(4): 527-544.

Frayne, B., W. Pendleton, J. Crush, et al.

2010 "The state of urban food insecurity in Southern Africa", AFSUN Series No. 2, Cape Town.

Global Commission on International Migration

2005 Migration in an Interconnected World: New Directions for Action, Geneva.

Hosegood, V., and I. Timæus

2005 "Household composition and dynamics in Kwazulu Natal, South Africa: mirroring social reality in longitudinal data collection", in E. Van der Walle (Ed.), African Households: Census Data, M.E. Sharpe, New York: 58-77.

Kok, P., M. O'Donovan, O. Bouare, and J. Van Zyl

2003 Post Apartheid Patterns of Internal Migration in South Africa, HSRC Publishing, Pretoria.

2006 Migration and Urbanisation in South Africa, Statistics South Africa, Pretoria.

Lerner, A., and H. Eakin

2011 "An obsolete dichotomy? Rethinking the rural-urban interface in terms of food security and production in the global South", Geographical Journal, 177(4): 311-320.

Lynch, K.

2005 Rural-Urban Interaction in the Developing World, Routledge, London.

Pendleton, W., and B. Frayne

2001 "Migration in Namibia: combining macro and micro approaches to research design and analysis", International Migration Review, 35(4): 1054-1085.

Pendleton, W. et al.

2007 "Migration, Remittances and Development in Southern Africa", in J. Crush (Ed.) Migration Policy Paper Series, 44, Southern African Migration Project, Cape Town.

Posel, D.

2006 "Moving on: patterns of labour migration in post-apartheid South Africa", in M. Tienda, S. Findley, S. Tollman and E. Preston-Whyte (Eds), Africa on the Move: African Migration and Urbanisation in Comparative Perspective, Wits University Press, Johannesburg: 217-231.

2010 "Households and labour migration in post-apartheid South Africa", Studies in Economics and Econometrics, 34(3): 129-141.

Posel, D., and D. Casale

2003 "What has been happening to internal labour migration in South Africa, 1993-1999", South African Journal of Economics, 71(3): 455-479.

2006 "Internal migration and household poverty in post-apartheid South Africa", in R. Kanbur and H. Bhorat (Eds), Poverty and Policy in Post-Apartheid South Africa, HSRC Press, Pretoria: 351-365.

Potts, D.

2006 "Urban growth and urban economies in Eastern and Southern Africa: trends and prospects", in D. Bryceson and D. Potts (Eds), African Urban Economies: Viability, Vitality or Vitiation?, Palgrave Macmillan, Basingstoke: 67-106. 
2008 "Recent trends in rural-urban and urban-rural migration in Sub-Saharan Africa: the empirical evidence and implications for understanding livelihood insecurity", Working Paper 6, Department of Geography, King's College, London.

2010 Circular Migration in Zimbabwe \& Contemporary Sub-Saharan Africa, James Currey, Woodbridge.

Ruel, M., J. Garrett, and L. Haddad

2008 "Rapid urbanization and the challenges of obtaining food and nutrition security", in R. Semba and M. Bloem (Eds), Nutrition and Health in Developing Countries: 2nd Edition, Humana Press, New York: 639-657.

South African Cities Network

2006 State of the Cities Report 2006, Johannesburg: 218.

Tacoli, C.

2003 "The links between urban and rural development", Environment and Urbanization, 15(1): 3.

Tienda, M., E. Preston-Whyte, S. Findley, and S. Tollman, eds.

2006 Africa on the Move: African Migration and Urbanisation in Comparative Perspective, Wits University Press, Johannesburg.

Todes, A., P. Kok, M. Wentzel, J. Van Zyl, and C. Cross

2010 "Contemporary South African urbanization dynamics", Urban Forum, 21(3): 331-348.

UN General Assembly

2006 International Migration and Development. Report of the Secretary-General, New York.

UN-HABITAT

2010 The State of African Cities 2010: Governance, Inequality and Land Markets, Nairobi: 207.

UNDP

2009 Overcoming Barriers: Human Mobility and Development, Human Development Report 2009, New York.

Vargas-Lundius, R., G. Lanly, M. Villarreal, and M. Osorio

2008 International Migration, Remittances and Rural Development, FAO and IFAD, Rome.

Zezza, A., C. Carletto, B. Davis, and P. Winters

2011 "Assessing the impact of migration on food and nutrition security", Food Policy, 36(1): 1-6. 